\title{
Karakteristik Stomata pada Berbagai Jenis Daun Pohon di Sekitar Kampus Universitas Timor
}

\section{Characteristics of Stomata in Different Types of Tree Leaves Around the University of Timor}

\author{
Kamaluddin $^{1 *}$, Gede Arya Wiguna ${ }^{2}$, Muhammad Rizki $^{3}$ \\ ${ }^{1}$ Program Studi Pendidikan Biologi, Fakultas Ilmu Pendidikan, Universitas Timor \\ ${ }^{2}$ Program Studi Biologi, Fakultas Pertanian, Universitas Timor \\ ${ }^{3}$ Program Studi Biologi, Fakultas Matematika dan Ilmu Pengetahuan Alam, Universitas Palangka Raya \\ *Alamat Email: kamaludin@ unimor.ac.id
}

\begin{abstract}
Abstrak - Penelitian ini bertujuan untuk mengetahui karakteristik stomata pada beberapa jenis pohon disekitar area kampus Universitas Timor. Penelitian dilaksanakan di Laboratorium Pendidikan Biologi Universitas Timor. Data yang diperoleh dianalisis secara deskriptif yaitu dengan mengamati stomata yang ditemukan pada daun, dan melakukan dokumentasi berupa foto. Pada pengamatan di lapangan 13 jenis tumbuhan ditemukan 4 tipe stomata yaitu parasitik seperti pada Filicium decipiens pada luas pengamatan 0,1372 $\mathrm{mm}^{2}$, anomositik pada Cocos nucifera pada luas pengamatan 0,0633 $\mathrm{mm}^{2}$, anisositik pada Gliricidia sepium pada luas pengamatan 0,1372 $\mathrm{mm}^{2}$, stomata aktinositik Anacardium occidentale dan Citrus aurantiifolia pada luas pengamatan $0,1372 \mathrm{~mm}^{2}$. Santalum album menampakkan jumlah stomata yang paling banyak yaitu 105 stomata, Dracaena fragrans hanya menampakkan 4 stomata. Cocos nucifera memiliki stomata dengan panjang $(28.7 \mu \mathrm{m})$ dan lebar stomata $(13.4 \mu \mathrm{m})$ yang lebih besar bila dibandingkan dengan stomata tumbuhan lainnya seperti Citrus aurantiifolia dengan Panjang $(6.3 \mu \mathrm{m})$ dan lebar $(5.05 \mu \mathrm{m})$.
\end{abstract}

Kata Kunci: stomata, karakteristik stomata, analisis deskriptif

\begin{abstract}
This study aims to determine the characteristics of stomata on several species of trees around the environment of University of Timor. The research was carried out at the Laboratory of Biology Education, University of Timor. The data obtained were analyzed descriptively by observing the stomata found on the leaves, and conducting documentation in the form of photographs. Four types of stomata were found in 13 types of plants, such as the parasitic in Filicium decipiens at $0.1372 \mathrm{~mm} 2$ observation area, anomositic in Cocos nucifera at $0.0633 \mathrm{~mm}^{2}$ observation area, anisocytic stomata type in Gliricidia sepium at $0.1372 \mathrm{~mm}^{2}$ observation area, and actinositic stomata type Anacardium occidentale and Citrus aurantiifolia at the observation area $0.1372 \mathrm{~mm}^{2}$. At the observation area of $0.1372 \mathrm{~mm}^{2}$, Santalum album consisted of 105 stomata. Dracaena fragrans only showed 4 stomata in the area of observation of $0.0633 \mathrm{~mm}^{2}$. Cocos nucifera has longer stomata $(28.7 \mu \mathrm{m})$ compared to other plants stomatas with the width $(13.4 \mu \mathrm{m})$. Meanwhile, the smallest length and width were Citrus aurantiifolia with the length $(6.3 \mu \mathrm{m})$ and width $(5.05 \mu \mathrm{m})$.
\end{abstract}

Keywords: stomata, characteristics stomata, descriptive analysis

(C) 2020 Jurnal Jejaring Matematika dan Sains. This work is licensed under a $\underline{C C B Y-N C 4.0}$

\section{PENDAHULUAN}

Tumbuhan hijau berfungsi sebagai produsen pertama, melalui proses fotosintesis gas $\mathrm{CO}_{2}$ dan $\mathrm{H}_{2} \mathrm{O}$ dengan bantuan sinar matahari dan klorofil dirubah menjadi karbohidrat dan oksigen. Setiap jam satu hektar daun-daun hijau menyerap 8 kilogram $\mathrm{CO}_{2}$ yang ekuivalen dengan $\mathrm{CO}_{2}$ yang dihembuskan oleh nafas 200 orang manusia dalam waktu yang sama [5].

Daun merupakan organ pokok pada tubuh tumbuhan. Pada umumnya berbentuk pipih bilateral, berwarna hijau, dan merupakan tempat utama terjadinya fotosintesis. Berkaitan dengan itu daun memiliki struktur mulut daun yang berguna untuk pertukaran gas $\mathrm{O}_{2}, \mathrm{CO}_{2}$, dan uap air dari daun ke alam sekitar dan sebaliknya [11].
Stomata adalah celah diantara epidermis yang diapit oleh 2 sel epidermis khusus yang disebut sel penutup. Di dekat sel penutup terdapat sel-sel yang mengelilinginya disebut sel tetangga. Sel penutup dapat membuka dan menutup sesuai dengan kebutuhan tanaman akan transpirasinya, sedangkan sel-sel tetangga turut serta dalam perubahan osmotik yang berhubungan dengan pergerakan sel - sel penutup. Stomata terdapat pada semua bagian tumbuhan yang terdedah ke udara, tetapi lebih banyak terdapat pada daun [8].

Tipe stomata pada daun sangat bervariasi. Berdasarkan hubungan stomata dengan sel epidermis sel tetangga ada banyak tipe stomata, klasifikasi ini terpisah dari klasifikasi berdasarkan perkembangan. Walaupun tipe yang berbeda dapat terjadi pada satu familia yang 
sama atau dapat juga pada daun dari spesies yang sama. Struktur apparatus stomata dapat digunakan dalam studi taksonomi [2]. Tipe stomata pada dikotil berdasarkan susunan sel epidermis yang berdekatan dengan sel tetangga ada 5 yaitu sbb:

1) Anomositik/Ranunculaceous yaitu sel penutup dikelilingi oleh sejumlah sel tertentu yang tidak berbeda dengan epidermis yang lain dalam bentuk maupun ukurannya. Terdapat pada Ranunculaceae, Cucurbitaceae Capparidaceae, dll.

2) Anisositik/Cruciferous yaitu setiap sel penutup dikelilingi oleh 3 sel tetangga yang ukurannya tidak sama, terdapat pada Cruciferae, Solanaceae

3) Parasitik/Rubiaceous

yaitu tiap sel penjaga bergabung dengan satu atau lebih sel tetangga, sumbu membu-jurnya sejajar dengan sumbu sel tetangga dan apertur, terdapat pada Rubiaceae dan Magnoliaceae.

4) Diasitik/Cariophyllaceus

yaitu setiap sel penutup dikelilingi oleh dua sel tetangga dengan dinding sel yang membentuk sudut siku-siku terhadap sumbu membujur stoma, terdapat pada Cariophyllaceae dan Acanthaceae.

5) Aktinositik

yaitu setiap sel penutup dikelilingi oleh sel tetangga yang menyebar dalam radius.

Modifikasi tipe-tipe tersebut dan tipe tambahan dapat terjadi pada spesies dari berbagai familia. Lebih dari satu tipe stomata terkadang terjadi bersama-sama pada organ yang sama. Von Cotthem menyatakan bahwa tipe stomata dewasa tidak hanya mempunyai nilai diagnosa tapi juga digunakan pada banyak kasus sebagai indikator kesamaan taksonomi secara alamiah, misalnya membedakan 15 tipe stomata pada paku-pakuan, gymnospermae dan angiospermae berdasarkan penampilan permukaan saja [2]. Letak stomata pada daun-daun dengan pertulangan menjala menyebar tidak teratur, sedang yang pertulangannya sejajar letaknya dalam barisan sejajar pula. Letak satu sama lain diperantarai jarak tertentu mempengaruhi intensitas penguapan. Jika jarak stomata terlalu dekat akan menghambat penguapan.

Pengeluaran air yang maksimal terjadi jika jarak antara stomata 20 kali diameternya [1]. Stomata dapat juga ditemukan pada mahkota bunga, putik, tangkai sari, daun buah dan biji tetapi biasanya stomata tersebut tidak berfungsi. Tujuan dilaksanakannya penelitian ini adalah untuk mengetahui karakteristik stomata pada beberapa jenis pohon disekitar area kampus Universitas Timor.

\section{Metodologi Penelitian \\ Jenis dan Lokasi Penelitian}

Penelitian dilaksanakan di Laboratorium Pendidikan Biologi Universitas Timor dimulai dari Desember 2019 Maret 2020 terhitung dari penyusunan proposal sampai pada penyusunan jurnal penelitian.

Penelitian ini adalah jenis penelitian deskriptif yang menggambarkan karakteristik stomata yang dilihat dari: tipe penyebaran stomata, bentuk sel penutup, jumlah sel tetangga, tipe stomata, ukuran stomata, sel epidermis dan derivatnya.

Metode pengumpulan data yang dilakukan adalah metode observasi dengan melakukan pengamatan pada daun pohon yang menjadi sampel dan dokumentasi.

\section{Alat dan Bahan}

Alat yang digunakan adalah gunting, kaca preparat, cat kuku (kuteks) bening, mikroskop digital dan selotip bening. Bahan yang digunakan adalah beberapa daun pohon yang terdapat disekitar kampus Universitas Timor.

\section{Analisis Data}

Data yang diperoleh dianalisis secara deskriptif yaitu dengan mengamati stomata yang ditemukan pada daun, dan melakukan dokumentasi berupa foto.

Tabel 1. Karakteristik Stomata tumbuhan disekitar kampus Unimor

\begin{tabular}{lllllll}
\hline No & Luas area & $\begin{array}{l}\text { Panjang } \\
\mathbf{p e n g a m a t a n} \\
\left(\mathbf{m m}^{2}\right)\end{array}$ & $\begin{array}{l}\text { lebar } \\
(\boldsymbol{\mu m})\end{array}$ & Bentuk & jumlah \\
\hline 1 & Filicium decipiens & 0,1372 & 18.2 & 15.3 & Parasitik & 16 \\
\hline 2 & Eucalyptus sp & 0,1372 & 25.7 & 18.8 & Parasitik & 22 \\
\hline 3 & Acacia auriculiformis & 0,0633 & 19.6 & 20 & Parasitik & 39 \\
\hline 4 & Melaleuca leucadendra & 0,0633 & 20.2 & 16.2 & Parasitik & 19 \\
\hline 5 & Dracaena fragrans & 0,0633 & 25.6 & 15.7 & Parasitik & 4 \\
\hline 6 & Cocos nucifera & 0,0633 & 28.7 & 13.4 & Anomositik & 12 \\
\hline 7 & Gliricidia sepium & 0,1372 & 20.5 & 12.1 & Anisositik & 52 \\
\hline 8 & Pterocarpus indicus & 0,1372 & 19 & 15.1 & Parasitik & 19 \\
\hline 9 & Santalum album & 0,1372 & 18.2 & 20.2 & Parasitic & 105 \\
\hline 10 & Citrus aurantiifolia & 0,1372 & 6.3 & 5.1 & Aktinositik & 52 \\
\hline 11 & Swietenia macrophylla & 0,1372 & 17.4 & 15.2 & Parasitik & 87 \\
\hline 12 & Borassus sp & 0,1372 & 18.3 & 26.3 & Diasitik & 21 \\
\hline 13 & Anacardium occidentale & 0,1372 & 20.2 & 19.8 & Aktinositik & 83 \\
\hline
\end{tabular}




\section{Hasil dan Pembahasan}

Hasil pengamatan stomata tumbuhan air dengan dengan menggunakan mikroskop digital ditunjukkan pada Tabel 1. Seperti terlihat pada tabel Filicium decipiens, Eucalyptus sp, Acacia auriculiformis, Melaleuca leucadendra, Dracaena fragrans, Pterocarpus indicus, Santalum album dan Swietenia macrophylla memiliki tipe stomata parasitik, Cocos nucifera memiliki tipe stomata anomositik, Gliricidia sepium memiliki tipe stomata anisositik dan Citrus aurantiifolia, Anacardium occidentale memiliki tipe stomata aktinositik.

Pada luas pengamatan $0,1372 \mathrm{~mm}^{2}$ Santalum album menampakkan jumlah stomata sebanyak 105 stomata, Dracaena fragrans hanya menampakkan 4 stomata pada luas bidang pengamatan sebesar 0,0633 $\mathrm{mm}^{2}$. Cocos nucifera memiliki stomata yang lebih panjang $(28.7 \mu \mathrm{m})$ dibandingkan dengan stomata tumbuhan lainnya, dengan lebar stomata $(13.4 \mu \mathrm{m})$ dan tumbuhan yang memiliki panjang dan lebar paling kecil ialah Citrus aurantiifolia dengan Panjang $(6.3 \mu \mathrm{m})$ dan lebar $(5.05 \mu \mathrm{m})$. Ukuran stomata berkaitan dengan ketahanan terhadap cekaman kekeringan daan dipengaruhi oleh penebalan sel penjaga terhadap respon cahaya, $\mathrm{CO}_{2}$, dan air [9]. Setiap tumbuhan memiliki ukuran stomata yang berbeda-beda, yang dipengaruhi oleh faktor internal seperti sifat genetiknya dan faktor eksternal yakni lingkungan tempat tumbuhan tersebut [7]. Lebih lanjut Gardner menyatakan semakin banyak jumlah daun maka semakin banyak jumlah stomata, sehingga semakin besar transpirasinya [11].

Besarnya ukuran stomata mampu meningkatkan laju transpirasi. Dengan transpirasi, laju unsur hara dan penyerapan air dapat berlangsung dan turgor yang berlebih dapat dicegah. Salah satu peranan air dalam fotosintesis adalah peningkatan fiksasi $\mathrm{CO} 2$ dalam daun, sehingga pertumbuhan tanaman meningkat [9].

Faktor lingkungan yang dapat memengaruhi ukuran, jumlah dan tipe penyebaran stomata yaitu intensitas cahaya, suhu udara dan $\mathrm{pH}$ tanah [6]. Didukung oleh pendapat Salisbury \& Ross menyatakan bahwa variasi ukuran stomata dipengaruhi oleh penebalan sel penjaga terhadap respon cahaya, $\mathrm{CO}_{2}$, dan konservasi air [3].

Transpirasi dipengaruhi banyak faktor, baik faktor dalam maupun luar. Faktor dalam antara lain jumlah daun, besar kecilnya daun, tebal tipisnya daun, berlapis lilin atau tidaknya permukaan daun, banyak sedikitnya bulu pada permukaan daun, banyak sedikitnya stomata, bentuk dan letak stomata. Sedangkan faktor luar antara lain kelembapan, suhu, cahaya, angin, dan kandungan air.

Dwijoseputro menyatakan bahwa distribusi stomata sangat berhubungan dengan kecepatan dan intensitas transpirasi pada daun, yaitu misalnya letak satu sama lain dengan jarak tertentu. Dalam batas tertentu, maka makin banyak porinya makin cepat penguapan. Jika lubanglubang itu terlalu berdekatan, maka penguapan dari lubang yang satu akan menghambat penguapan lubang dekatnya [4].

\section{Kesimpulan}

Pada pengamatan dilapangan dengan 13 jenis tumbuhan ditemukan 4 tipe stomata yaitu parasitik seperti pada Filicium decipiens pada luas pengamatan 0,1372 $\mathrm{mm}^{2}$, anomositik pada Cocos nucifera pada luas pengamatan $0,0633 \mathrm{~mm}^{2}$, tipe stomata anisositik pada Gliricidia sepium pada luas pengamatan $0,1372 \mathrm{~mm}^{2}$, stomata aktinositik Anacardium occidentale dan Citrus aurantiifolia pada luas pengamatan $0,1372 \mathrm{~mm}^{2}$. Santalum album menampakkan jumlah stomata yang paling banyak yaitu 105 stomata, Dracaena fragrans hanya menampakkan 4 stomata. Cocos nucifera memiliki stomata dengan panjang $(28.7 \mu \mathrm{m})$ dan lebar stomata $(13.4 \mu \mathrm{m})$ yang lebih besar bila dibandingkan dengan stomata tumbuhan lainnya seperti Citrus aurantiifolia dengan panjang $(6.3 \mu \mathrm{m})$ dan lebar $(5.05$ $\mu \mathrm{m})$.

\section{Daftar Pustaka}

[1] Dwijoseputro, D. 1978. Pengantar Fisiologi Tumbuhan. Jakarta: PT Gramedia.

[2] Fahn A. 1991. Anatomi Tumbuhan, Edisi ke-3. Gadjah Mada University Press: Yogyakarta.

[3] Hafiz P, Dorly, Rahayu S. 2013. Karakteristik anatomi dari

daun sepuluh spesies Hoya suklen sertaanalisis hubungan kekerabatannya. Buletin Kebun Raya. 16(1):58-73

[4] Haryanti.S.2010. Jumlah dan Distribusi Stomata pada Daun Beberapa Spesies Tanaman Dikotil dan Monokotil Laboratorium Bio logiStruktur dan Fungsi Tumbuhan Jurusan Biologi F. MIPA UNDIP, 2010.

[5] Irwan, Z. D. 1992. Prinsip-prinsip Ekologi dan Organisasi Ekosistem Komunitas dan Lingkungan. Bumi Aksara. Jakarta.

[6] Jaya, A. B., Tambaru, E., Latunra, A. I., dan Salam, M. A., (2015). Perbandingan Karakteristik Stomata Daun Pohon Leguminosae di Hutan Kota Universitas Hasanuddin dan di Jalan Tamalate Makassar. Jurnal of Biological Diversity. 7 (1): 6.

[7] Juairiah, L. (2014). Studi Karakteristik Stomata Beberapa Jenis Tanaman Revegetasi di Lahan Pasca Penambangan Timah di Bangka. Widyariset. 17 (2): 213-218.

[8] Pandey, B.P. 1982. Palnt Anatomy. S Chand and Company. New Delhi

[9] Salisbury, FB. \& CW. Ross. 1995. Fisiologi Tumbuhan. Terjemahan: Lukman, DR. \& Sumaryono. Bandung: Penerbit ITB.

[10] Sumardi, I., Nugroho, H., dan Purnomo. 2010. Struktur dan Perkembangan Tumbuhan. Jakarta Penebar Swadaya.

[11] Suyitno. 2012. Perbandingan jumlah stomata pada bagian abaksial dan adaksial. http://www.pertanian.untag-smd.ac.id/wpcontent /uploads/2012/06/Proses_Transpirasi_PadaTana man Bab IX.pdf 